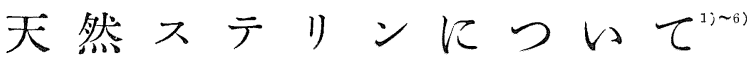

松 本太 郎*

\section{Naturally Occurring Sterols}

Taro MAtsumoto

\section{I. ステリンの構造}

最初胆石から分離された結晶性物質はコレステリン 乙命名され，これが多くの動物脂質涪まれることがわ かつたが，その後植物からシトステリンが，麦角（ばつ かく）からエルゴステリンが，さらにカラバル豆からス チグマステリンが発見され，李た人糞からコプロステリ ンが分離された。こうしてステリン成分の検索の対象が 順次拡げられ，動物として春椎（せきつい）動物や代謝 生成物の及ならずさらと下等動物に, 植物とついては顕 花植物種子油のみならず㩊花植物の菌類, 藻類に及び, 今日天然物から発見されたステリンの総数は数十種に達 している。今後さらと精查すれぶな特新しいものも発見 できると思われる。

今日末で化学構造が明らかとされているるのは，す べて $\mathrm{C}_{27}, \mathrm{C}_{28}$ 扝よび $\mathrm{C}_{29}$ のすので, $\mathrm{C}_{27}$ のステリンはす ベてコレステリンと 同一の炭素原子の配列をなし， $\mathrm{C}_{28}$ 特よび $\mathrm{C}_{29}$ のステリンはコレステリンの $\mathrm{C}_{24}$ がメチル基 (またはメチレン基) あるいはエチル基（またはエチリ デン基）で置換されたるのである。これらに対して古く からラノステリン (羊毛脂) なぞの名称で $\mathrm{C}_{30}$ のステリ ンが数種知られている。これらもまたコレステリンと同 一の炭素原子の配列を有するが，さらに 3 個のメチル基 が $\mathrm{C}_{4}$ (2 個) 怙よび $\mathrm{C}_{14}$ 江置換している構造で, 現在 トリメチルステロイドなる新しい一群の化合物として报 われて特り，コレステリンあるいはとの $\mathrm{C}_{24}$ 置換体のス テリンとは多少化学的性質も異㣕ている。

コレステリンは Rosenheim, King (1932), Wieland, Dane (1932) 飞よつてシクロペンタノパーヒドロフェナ ントレン核の構造式が明らかねされ，現在構造既知の天 然ステリンはコプロステリン特よびエピコプロステリン を除けばコレステリンと同様で, A : B 環， B : C 環, $\mathrm{C}: \mathrm{D}$ 環の結合がいずれるトランス形の $3 \beta$-オキシ化合 物である。

コレステリンの全合成が Cornforth, Robinson ${ }^{7)}$

* 日本大学工学部 (千代田区神田駿河台)

Faculty of Engineering, Nihon University
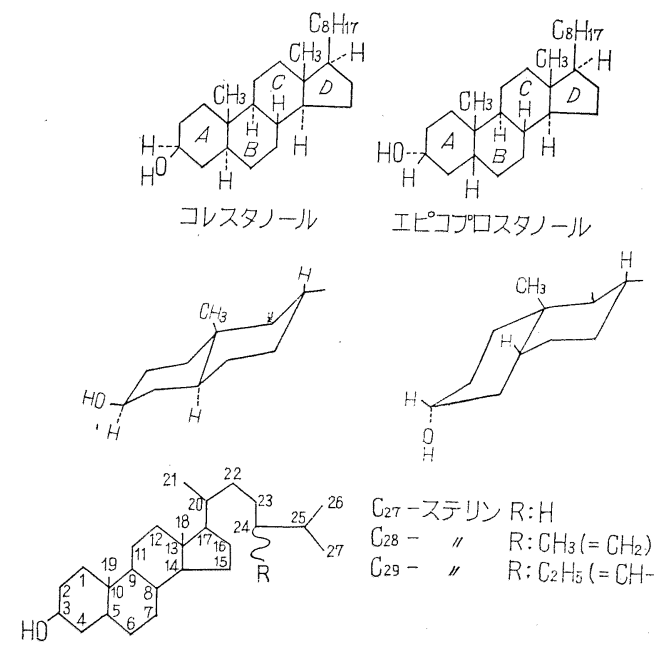

$\mathrm{C}_{27}$ ーステリン $\mathrm{R}: H$

$\mathrm{C}_{28}-\quad$ " R: $\mathrm{CH}_{3}\left(=\mathrm{CH}_{2}\right)$ $\mathrm{C}_{29}-$ " $\mathrm{R}: \mathrm{C}_{2} \mathrm{H}_{5}\left(=\mathrm{CH}-\mathrm{CH}_{3}\right)$

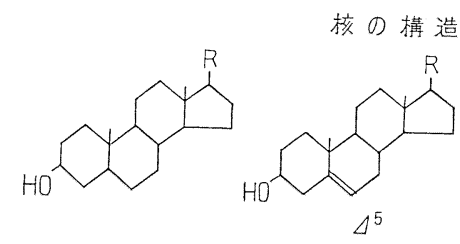

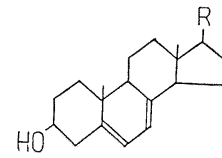

$\Delta^{5,7}$
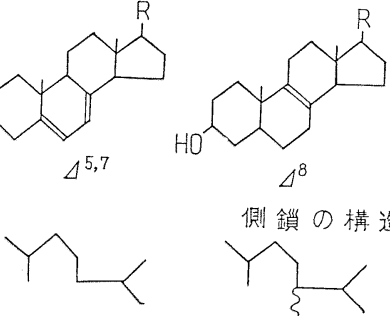

側鎖の構造

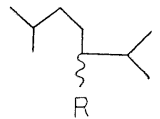

$\mathrm{R}: \mathrm{H}-, \mathrm{CH}_{3}-\mathrm{C}_{2} \mathrm{H}_{5}$

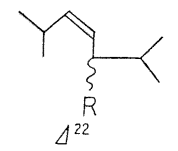

$\mathrm{R}: \mathrm{H}-, \mathrm{CH}_{3}-, \mathrm{C}_{2} \mathrm{H}_{5}-$

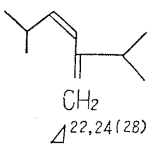

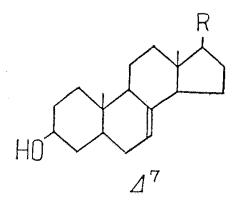
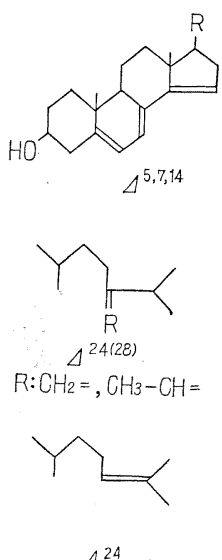
(1949，1953) 飞よつて 1,6-ジオキシナフタリンから 30 行程で, Woodward ${ }^{8)}$ ら (1952) 飞よつて 4-メトキ シ-2,5-トルノンから 20 行程でとれぞれ 3-ケトエチオ アロコラン酸メチルを作り，既知のコレスタノールある いはコレステリンと至る方法" を用いて完成されること が明らか、された。また動物体内での生合成については Block $5^{10)}$ 飞より放射性 ${ }^{14} \mathrm{C}$ 原子を用いて, 酢酸から アセト酢酸を生じ，これが脱炭酸してアセトンとなり， さらに酢酸が反応して $\beta$-ジメチルアクリル酸となり, これが縮合してコレステリンとなることも明らかにされ た。

コレステリンを基本とする天然の $\mathrm{C}_{27}, \mathrm{C}_{28}$ および $\mathrm{C}_{29}$ ステリンね二重結合の数和よびその位置, 側鎖 $\mathrm{C}_{24}$ 和よ び $\mathrm{C}_{20}$ そ新ける置換基の立体配置の差異による多くのス テリンが存在する。二重結合は最高 4 個まで知られてい るが, その位置は核では $5: 6,7: 8,8: 9,14: 15$, 側 鎖では $22: 23,24: 25,24: 28$ で, その他の位置のる のも二, 三報告されている。 $\mathrm{C}_{24}$ 飞挌ける置換基の立体 配置はエルゴステリンあるいはスチグマステリンと同一 配置のものを “b”で表わし4)，これと反対の結合のもの を“a”で表わしている。 $\mathrm{C}_{20}$ に和ける立体異性体も， 二，三報告されているが，これるコレステリンの結合と 反対のものを“a”で表わしている。

\section{II. ステリンの呈色反応, 旋光性など}

ステリンは広く動植物（細菌類には存在しないとされ ている）飞含まれるが，単独存在することはなく，必 ず幾種かのステリンの混合物となつている。これらのス テリン混合物の分別は一般にはなはだ困難で, 数十回の 再結晶を行つて子純粋に分別できない場合が多い。ま たクロマトグラフ法でも構造類似のステリン群に大別で きるが，それ以上の分別には十分目的を達し得ないこと も多い。またステリンは他のステリンと混融しても融点 降下しないのが普通のようで，十分精製したつもりのス テリンが実は未精製物である場合も多い。このような結 果，同一のステリンを主成分とするものでも原料によつ て多少性状が異なつたり，また新ステリンと報告された すのが㙂知ステリンホたは混合物であつたということに もしばしば遭遇し，数党あげれば枚挙にいとまないほど である。このことは天然のステリン成分を検討する上に 呿いて最も留意すべき点であり,さらにステリンの分離 法の研究，目的のステリンを純粋に得やすいような試料 の探求もまた重要なことであろう。

ステリン骨核に不飽和結合をもつステリンは強酸なぞ の脱水条件で特異な呈色反応を示すが，核の飽和のステ リンは作用しないので，この反応を利用して核飽和のス テリンを分離することができる。呈色反応は核の不飽 和結合の構造, あるいはとの位置によつて異なり,
Rosenheim 反応は $4^{5,7}$-ステリンに, Tortelli-Jaffé 反 応は $\Delta^{5,7}$-ステリン， $\Delta^{7}$-ステリンのような $\mathrm{C}_{8}$ 位などに 二重結合をるつステリンに特有のものである。さらに Liebermann-Burchard 反応はコレステリンなどでは, $400 \mathrm{~m} \mu$ 和よび $620 \mathrm{~m} \mu$ V吸収極大を持つ呈色をするが， ラノステリンなどは $550 \mathrm{~m} \mu$ と吸収極大を示す。またこ の反応は $\Delta^{5}$-ステリンでは反応後やや誘導期間を和いて 徐々に呈色が強くなつていくが， $4^{5,7}$ ーステリン， $\Delta^{7}$-ス テリンでは短時間に非常に強く呈色し, 数分後には徐々 そ退色していく。このことほ Idler, Baumann"11)によつ て定量的に検討され, ステリンの核構造の判定に便利で ある。また中西, Fieser ら ${ }^{12)}$ は $\Delta^{7}$ ーステリンの特異な 酸化性を利用して酸化セレンからセレンを遊離させ，こ のセレンを測定して $\Delta^{7}$ ーステリンの定量をしている。

ジギトニンは通常の $3 \beta$-オキシ構造のステリンと難溶 性分子化合物を作るが臭化物とは作用しない。とこで天 然ステリンから飽和ステリンを分別するには，ステリン 混合物を臭素化し，これにジギトニンを作用して分別す ることができる13)。

つぎにステリンの旋光性についても深く研究されてい る。ステリンは数多くの不齊炭素原子を含み旋光性を示

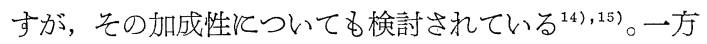
遊離スデリンの旋光性と誘導体のそれとの間に，一定の 関係のあることが知られている ${ }^{16)} 。 \Delta^{5,7}$ ーステリンでは側 鎖にエチレン結合の有無にかかわらず $[\alpha]_{\mathrm{D}}-71$ $132^{\circ}$ の範囲に㟧るが，酢酸エステルの分子旋光度と遊離 ステリンのそれとの差は $+120 \pm 43^{\circ}$ ，安息香酸エステル の場合は $+185 \pm 15^{\circ}$ であり, $\Delta^{5}$-ステリン $\left([\alpha]_{\mathrm{D}}-33^{\circ} \sim\right.$ $\left.-64^{\circ}\right)$ では前者が $+35 \pm 16^{\circ}$, 後者が $+81 \pm 16^{\circ}, \Delta^{7}-$ ス テリン $\left([\alpha]_{\mathrm{D}}-20^{\circ} \sim+6^{\circ}\right)$ では, 前者が $+15 \pm 15^{\circ}$, 後: 者が $+20 \pm 14^{\circ}$ ，スタノール $\left([\alpha]_{\mathrm{D}}+19^{\circ} \sim+28^{\circ}\right)$ では前 者が $-34 \pm 11^{\circ}$, 後者が $+2 \pm 3^{\circ}$ であることが知られて いる。な和近年発見された $\Delta^{5,7,14}$ ーステリン ${ }^{17)}$ は旋光度 が最も左旋性で, $[\alpha]_{\mathrm{D}}-396^{\circ}$ を示している。

\section{III. ステリンの吸収スペクトル ${ }^{18), 19)}$}

紫外部, 赤外部吸収スペクトルはステリンの研究に和 いても重要な手段で, 紫外部吸收スペクトルでは 190〜 $205 \mathrm{~m} \mu$ 付近の吸収が エチレン結合の測定にしばしば用 いられるが，一般の水晶紫外の波長域では側鎖の共役ジ エン結合は $230 \mathrm{~m} \mu$ 付近飞, 核の $\Delta^{5,7}$ 共役ジェンは 272 $\mathrm{m} \mu, 282 \mathrm{~m} \mu$ 和よび $293 \mathrm{~m} \mu$ 飞吸収極大を示す。また近 年分離された $\Delta^{5,7,14}$-ステリン ${ }^{17)}$ では $319 \mathrm{~m} \mu$ に極大を 示す。ステロイドの紫外部吸収スペクトルについては Woodward ${ }^{20)}$ により共役ジエンが同一環内か，あるいは 他環に連続的であるか、よつて，をた共役ジェンの炭素 にある置換基の数，さらにエキソ環状をなすかどうかな ぞによつて吸収極大の波長がずれるが，それが一定の法。 
則によつていることが明らがされた。これはステリン の構造研究に大変便利である。

共役ジェン結合をもつ天然ステリンは $4^{5, i}$ ーステリン が最も普通であるが，それの定量には不ケン化物からス テリンを分別することなく, ジギトニン溶液を作用して 90\%エタノール難溶性ジギトニドを生成分取し，乙れの 100\%エタノールあるいはメタノール溶液で紫外部吸収 スペクトルを測定し，そしてそのスペクトルが $\Delta^{5,7}$-ステ リンのそれに相似であれね゙ $282 \mathrm{~m} \mu$ の吸収極大, あるい 洁 $277 \mathrm{~m} \mu, 282 \mathrm{~m} \mu, 290 \mathrm{~m} \mu$ の 3 点の吸光係数から $4^{5,7}$

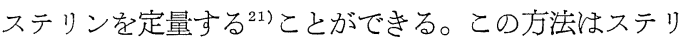
ン以外の不純物の影響がなく，また操作による $4^{5,7}$ ーステ リンの変化和よび易溶性部の損失が少なく, 定量に便利 である。

な杼，近年 Breivik らによつて発見された 24 (28)ーデ ヒドロエルゴステリン ${ }^{22)}$ は側鎖共役ジエン結合を有し， $230 \mathrm{~m} \mu$ に8吸收極大を示す。

赤外部吸収スペクトルもをた構造の研究に有效な手段 で，これは溶液法または Nujol 法で調べられるように なつた。 $\Delta^{5}$-ステリン， $\Delta^{7}$-ステリンでは $\mathrm{RR}^{\prime} \mathrm{C}=\mathrm{CR}^{\prime \prime} \mathrm{H}$ の三置換エチレン結合によつて吸収極大が 850 790 $\mathrm{cm}^{-1}$ 飞一対現われる。 $4^{5,7}$-ステリンではこの結合が一 分子内に 2 個あり，共役しているのでその四収は強い。 $\Delta^{8}$-ステリンは $\mathrm{RR}^{\prime} \mathrm{C}=\mathrm{CR}^{\prime \prime} \mathrm{R}^{\prime \prime \prime}$ の四置換エチレン結合 でこれとよる吸収はない。側鎖の $\Delta^{22}$ 結合はステリン ではトランス形のみ知られているが, 1305 1290 $\mathrm{cm}^{-1}$ 拉 よび $1673 \mathrm{~cm}^{-1}$ 付近の弱いるのが現われる。 $\Delta^{24(28)}$ 結合 では，メチレン基 $\left(\mathrm{RR}^{\prime} \mathrm{C}=\mathrm{CH}_{2}\right)$ の場合とエチリデン基 $\left(\mathrm{RR}^{\prime} \mathrm{C}=\mathrm{CH}-\mathrm{CH}_{3}\right)$ とでは異なり，後者は三置換エチレ ン結合で前述のようマ 850 790 $\mathrm{cm}^{-1}$ 飞一対の吸収極大 を示す。フコステリンの場合ではこの結合のほかに核に $\Delta^{5}$ 結合があるので，両者の吸収が多少ずれて 3 4 本認 めることができる ${ }^{23)}$ 。前者のメチレン基の場合は二置換 エチレン結合で 885 985 $\mathrm{cm}^{-1}$ 強く， 1420 1410 $\mathrm{cm}^{-1}, 1800 \sim 1750 \mathrm{~cm}^{-1}$ V弱く, $1653 \mathrm{~cm}^{-1}$ 付近飞中程 度の吸収がある。24-メチレンコレステリン ${ }^{24)}$ では 890

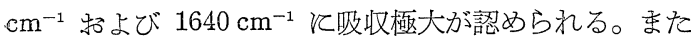
この吸収は $\Delta^{25}$ あるいは $\Delta^{20}$ の場合でも現われるはずで 岗り，ビタミンDの $\Delta^{10(19)}$ でも認められる。

\section{IV. ステリンの分類}

天然ステリンの種類があまり知られていない初期のこ

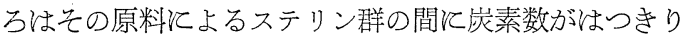
区別されるかにみえた。すなわち動物脂質に含まれるス テリン (zoosterols) は $\mathrm{C}_{27}$, 植物脂質に含まれるもの (phytosterols) $2 \mathrm{C}_{29}$, 菌類脂質に含まれるもの (mycosterols） は $\mathrm{C}_{28}$ であつたが，その後無脊椎動物からチ

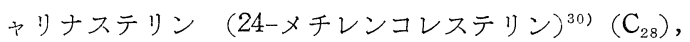

表-1

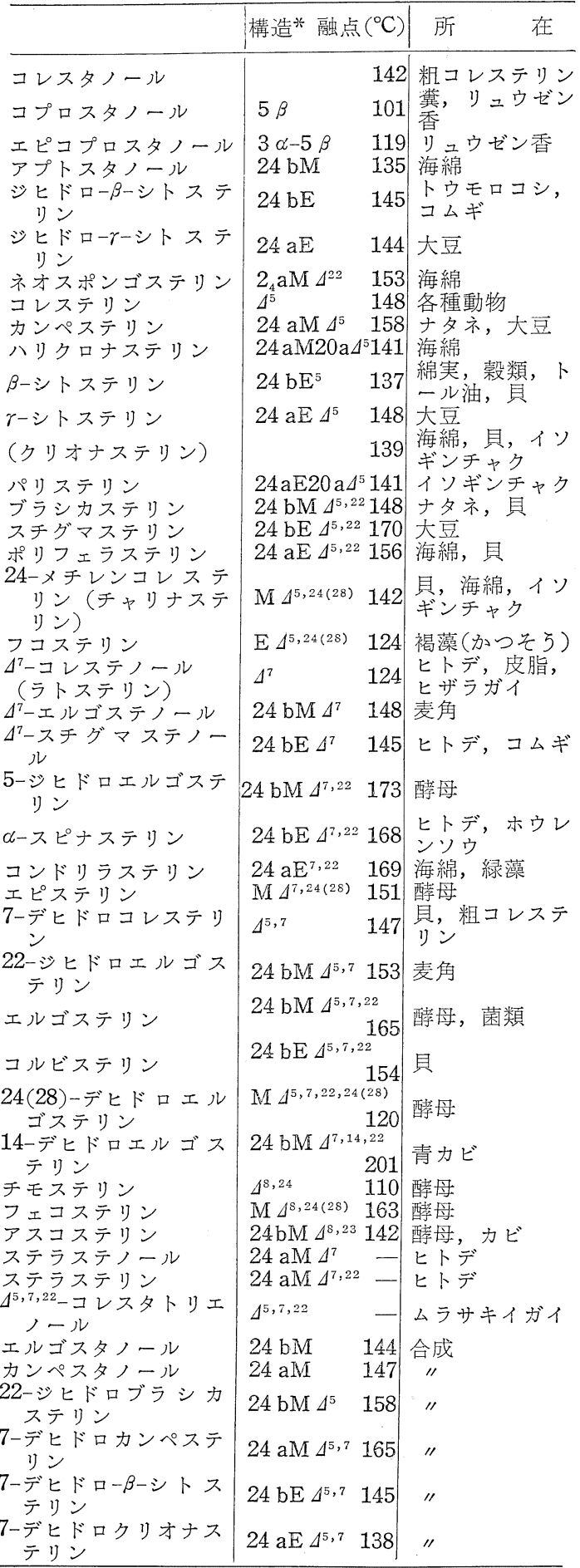

*構造はコレスタノール骨核を主体とし，これと異な つた結合 $\left(\alpha, \beta\right.$ とか $20 \mathrm{a}$ とか), $\mathrm{C}_{24}$ の置換基（メ

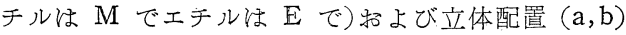
とした。 
クリオナステリン $\left(\mathrm{C}_{29}\right)$ やポリフェラステリン $\left(\mathrm{C}_{29}\right)$ が, またナタネからブラシカステリン $\left(\mathrm{C}_{28}\right)$ やカンペステリ ン $\left(\mathrm{C}_{28}\right)$ が，さらに酵母からチモステリン $\left(\mathrm{C}_{27}\right)$ が発見 され，さらに植物脂質から分離されたブラシカステリン 特よび $\beta$-シトステリンが貝に， $\alpha$-スピナステリン， $\Delta^{7}$ スチグマステノールがヒトデに見いだされ，またクリオ ナステリンも でステリンの原料と炭素数との関係, あるいはステリン の動植物的種別ははつきりしたるのでなくなつてきた。 現在ステリンの分類法は主として旋光度すなわち構造に よることが多くなつてきた。また原料による場合でも plant sterol とか marine sterol などの呼称を用いるこ とが多くなつているようである。現在構造の確実と考皇 られるステリンの構造，性状拈よび所在を示せば表一1 のと祘りである。

\section{V. ステリンの分布 ${ }^{1) \sim 3(, 6), 25)}$}

\section{動物界}

会椎動物にはコレステリンが遊離状をたはパルミチン 酸，オレイン酸なぞのエステルとして各種組織と含まれ ている。血液にはコレステリンが $100 \mathrm{cc}$ 中 $0.15 \sim 0.25$ $\mathrm{g}$ 含まれるが，その $26.9 \pm 1.4 \%$ ほ遊離のもので山るこ とが知られている。各種動物の各種器官のコレステリン 含有率は相当くわしく調べられているが26)，人では病的 産物の䏣石が医とんぞコレステリンからなつている(98 ～99\%）。委无皮脂肪には 13～24\%，幼児の毛髪脂肪 には 8.7〜11.8\%，物となでは 1.2〜5.4\%, suprarenal

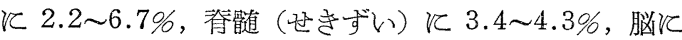
$2.7 \%$ など大きい含有率を示す。毛，将毛の脂肪にはコ レステリンが多くウサギで 33.9 41.2\%，ヒツジで 6.3 〜 12.5, 七面鳥で 14.1 25.8\% というデータも見られ る。工業的にはウシの脳 $(24 \%)$, 倠髄, 魚油 (Halibut 肝油， 7.6\%) や羊毛脂などが用いられる。

な特最近植物の紅藻にもコレステリンが存在すると津 田，赤木，岸田によつて報告された ${ }^{66) 。}$

粗コレステリンに付随してコレスタノール，ラトステ リン (47-コレステノール)や7-デヒドロコレステリンな ぞが存在するが, 含有率は一般飞比較的少ない。たとえば 胆石のステリン中には飽和ステリンが 1.2 1.9\%，脳で も 1.2\%である。しかし羊毛の場合注 14.3 18.9\%,さ らに海綿では含有ステリン中 $50 \%$ を越光る種類もある。 人粪や肉食動物の糞中には核の A : B 環がシス構造の コプロステリンが存在するが，これはコレステリンの代 謝生成物であり，因を与えないで飼つたイヌの糞には見 いだされない。コプロステリンはマッコウ鯨の病的産物 であるリュウゼン香にも含まれ，リュウゼン香にはこの ほか 3 济オキシ化合物 (A：B 環はやはりシス形のエピ コプロステリンも含まれている。これは石黒, 渡辺ら ${ }^{27)}$
によりて見いだされた。

春椎動物のステリンは $\mathrm{C}_{27}$-ステリンであるが， $\mathrm{C}_{28}$ r $\mathrm{C}_{29}$ のステリンも報告されている。大滝 ${ }^{28)}$ によてヒキ ガエルには rーシトステリンの存在が明らかにされて特 り，また鵎卵にエルゴステリンが含まれていることが知 られているが，これは食物によるもので鷄卵本来のステ リンではない。

無脊椎動物のステリンについては Henze (1904) や Doreè (1909) 飞よつて研究され始め，広く動物の種別 についてコレステリンの存否が調べられ，コレステリン 以外のステリンの存在や棘皮（きよくひ）動物にコレス テリンが存在しないことが報告されて，無篒椎動物の ステリン成分の検索が注目されるようになつた。乞の後 Bergmann は海綿，貝，ヒトデ，イソギンチャクなどの ステリンを広く検討し，それらの組成，新ステリンの発 見招よび構造決定など貴重な研究を行つた。

海綿のステリンは含有ステリンの種類も多く，たと光 ぼコレステリン，コレスタノール，ネオスポンゴステリ ン，八リクロナステリン，アプトステリン，チャリナス テリン (24-メチレンコレステリン), ポリフェラステリ ン, コンドリラステリン, さらに $\Delta^{5,7}$-ステリン（多い.

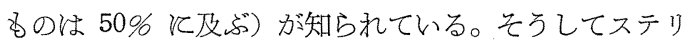
ン成分の組成によつて海綿の種別が分類されるといるれ ている。ネオスポンゴステリンは最初スポンゴステリン として得られたものであるが，コレスタノールが混在し ていることが明らかれされて新たに命名された。このス テリンは還元するとカンペステリンとなり，オゾン分解 すると $d$-メチルイソプロピルアセトアルデヒドを与光 る。アプトステリン（アプトスタノール）は還元生成物 がエルゴスタノールともカンペスタノールとも一致しな いが，ハリクロナスタノールと同一物であると考党ら れ，旋光度から C-24 a C-20 a の配置をもつとされて いる。しかし旋光度からだけの構造推定は確証にならな いことが多いので, さらに検討する必要があると思われ る。ハリクロナステリンは旋光度から $4^{5}$ ーステリンとさ れた。チャリナステリンは部分還元するとカンペステリ ンとなり，またオゾン分解で $d$-メチルイソプロピルア セトアルデヒド（？）を与劣るところから $24 \mathrm{a}$ をメチルの $4^{5,22}$ 一ステリンとされたが，最近イソギンチャクから得 られたチャリナステリンが再検討された。との結果赤外 部吸収スペクトルでメチレン結合が認められ，オゾン分 解でホルムアルデヒドが得られ，さらにコレステリンか ら得られる 3-オキシー5-コーレン酸20)を経て合成される $24-メ チ レ ン コ レ ス テ リ ン ~\left(4^{5,24(28)}\right)$ と比較されて同一 構造であると訂正された ン分解で $d$-エチルイソプロピルアセトアルデヒドなど の生成が確認され，また部分還元でクリオナステリンを 生ずることから $24 \mathrm{a}$-エチルの $\Delta^{5,22}$-ステリンとされた。 
クリオナステリンは古くは混合物と与兄られた名称であ るが，これからさらと共存するステリンを除い精製され た。これはポリフェラステノールと一致するので $24 \mathrm{a}$ エチルの $\Delta^{5}$-ステリンである。性状は多少相違するが $r$ シトステリンと同一物とされている。コンドリラステリ ンは旋光性が低く，オゾン分解で $d$-エチルイソプロヒ ルアセトアルデヒドを与光, 接触還元で核内のエチレン 結合が残るが，これは塩化水素で異性化されて還元を受 け，還元生成物はポリフェラスタノールと一致すること から $24 \mathrm{a}$-エチルの $\Delta^{7,22}$-ステリンとされた。これらの ほか海綿のステリンとして 5-ジヒドロスチグマステリ ンが報告されたが，午の性状は合成物の性状とは全く違 い，むしろクリオナステリンの性状飞一致している。

腔腸（こうちよう）動物のステリンもまた Bergmann によつて多く研究されている。ステリン成分としては 24-メチレンコレステリン， $\beta$-シトステリン，パリステ リン，コルゴステリンなどが知られている。パリステリ ンはイソギンチャクから得られ，その旋光性から C- 24 a, C-20 a の配置をもつ $\Delta^{5}$-ステリンとされた。 $\beta$-シト ステリンは外山ら ${ }^{311}$ 亿よつてイソギンチャクから分離さ れた。24-メチレンコレステリンは前述のよろと最近チ ャリナステリンの構造が訂正された。コルゴステリンは $\mathrm{C}_{30} \mathrm{H}_{52} \mathrm{O}$ または $\mathrm{C}_{30} \mathrm{H}_{54} \mathrm{O}$ が与兄られているので通常の ステリン系ではないらしい。

棘皮動物のステリンは Doreé とよつて最初コレステ リンが存在しないことが報告された。ヒトデのステリン としてKossel らがステラステリンを発表したが, Bergmann はヒトデ Asterias forbesi のステリンがステラス テリンとステラステノールの混合物であり, 両者は分離 され難いとした。そうしてとの混合物の部分還元でステ ラステノールを与克, 異性化を伴なう還元でステラスタ ノ一ルを生ずるが，これがエルゴスタノールとるカンペ スタノールとも一致しない。一方ステリン混合物のオゾ

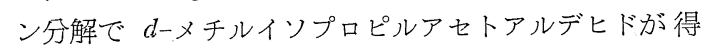
られるところからステラステリンは $24 \mathrm{a}$-メチルの $\Delta^{7,22}$ 一ステリン，ステラステノールは $\Delta^{7}$ ーステリンとされた。 しかし混合ステリンが同一炭素数の 2 種類のステリンの みと考党るのは危険である。

松本, 外山らはヒトデ Asterias amurensis などから ヒトデステリンを得たが，その後これはオゾン分解, 異

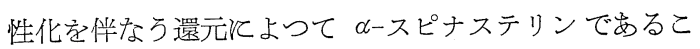
とを明らか沉 ${ }^{322}$ ，また他のステリン成分として $\Delta^{7}-コ$ レステノール， $\Delta^{7}$-スチグマステノールを単離した ${ }^{33)}$ 。 スピナステリン， $\Delta^{7}$ ースチグマステノールの存在は動物 界では知られていなかつた。さらとヒトデの粗ステリン 泥合物のオゾン分解生成物からステラステリンの存在る 推測している。棘皮動物でもヒトデ綱,ナマコ綱, ウミユ リ綱のステリン主成分は呈色反応から $\Delta^{7}$-ステリンで,
ウニ綱, ダビ綱では $\Delta^{5}$-ステリンであるとしている ${ }^{34)} 。$ な特クモヒトデ (ダビ綱) のステリンとしては松本, 田村 $ら^{35}$ Vよつてポリフェラステリン，スチグマステリン， クリオナステリン和よび $\beta$-シトステリンが分離された。 桑田, 伴ら ${ }^{36)}$ はイトマキヒトデからパチリアステリン を得て,その旋光性などから $\mathrm{A}: \mathrm{B}$ 環がシス形の $\Delta^{22}$ 一ステ リン $\left(\mathrm{C}_{28}\right)$ としている。乙かし旋光度の加成性はあまり そるファクターが多く, 得られるステリンの純粋性にる 左右されまた A：B 環がシス形であると結論するのも 天然ステリンとしては希有の感があり，むしろ $\Delta^{7}$-ステ リンであろろと思われる。

節足動物のステリンとはコレステリン, シトステリン が知られている。シトステリンは食物によるものと思わ れ，サナギのボンビセステリン，イナゴのイナゴステリ ンは $\beta$-シトステリンと性状が良く似ている。

軟体動物のステリンは最初 Bergmann とよつてオス トレアステリン (24-メチレンコレステリン), スチグマ ステリンの存在が報告され, カキのステリンに東 ${ }^{377}$ そよ つてマガキステリンが報告された。辻本, 小柳らはカ キ,アサリ，ハマグリなぞ 12 種からコンカステリン38) を，またシャコガイのシャコステリン 委発表した。 松本, 外山ら ${ }^{40)}$ はシジミ, カキにブラシカステリンの存 在を認めた。ブラシカステリンの存在はさらに Berg mann 扮よびvan der Vliet 飞よつて貝炕含まれること がわかり ${ }^{41}$ ，植物から分離されたステリンが動物にる含 まれることが初めて示された。シャコステリンも，また 前述の貝から得られたスチグマステリンもむしろブラシ カステリンではないかと思われる。また桑田, 吉城ら ${ }^{42)}$ はホタテガイからペクトステリンを得をと発表してい る。最近では足利 ${ }^{43}$ とよてアコヤガイからピンクステ リンが分離されている。しかし貝のステリン, 殊に二枚 貝では成分が複雑でポリフェラステリン, クリオナステ リン， $\beta$-シトステリン，コレステリン，24-メチレンコ レステリン, $\Delta^{5,7}$-ステリン $2 \sim 3$ 種類の存在が考兄られ るので, 得られたステリンが未精製のるのもあるのでは ないかと考光られる。24-メチンンコレステリンは, 最近 Idler ら ${ }^{24), 44}$ が数種の貝のステリン混合物をアゾ安息 香酸エステルとし, クロマトグラフィーで単離したるの で, 赤外部吸收スペクトル, オゾン分解（ホルムアルデ ヒド生成),さら飞 24-ケトコレステリンからトリフェニ ルホスフィンメチレン試楽によつて合成確認されたも ので, このような $\mathrm{C}_{24}$ の結合から a の配置または b 配 置のステリンができるのであろろとしている。一方

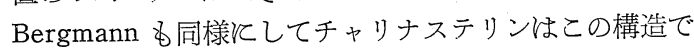
めると訂正した午 ${ }^{30)}$ 。ヒザラガイには $\Delta^{7}$-コレステノール が含まれることが外山ら ${ }^{45), 46)}$ とよつて確認された。

また巻貝のある種のもの（アワビ, サザエなぞ）はコ レステリンが主成分であるが，さらと複雑な成分のもの 


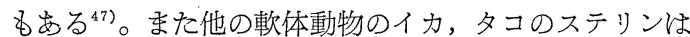
注とんぞコレステリンから成つている。おた田中，外山 $ら^{48)}$ はナメクジ沉 $\beta$-シトステリンの存在を認めてい る。さら飞 $4^{5,7}$ ーステリンについてる具類が多く研究さ れている。Bock, Walter は, エゾバイの一種 Buccium undatum のステリンから 7-デヒドロコレステリンの融 点飞近いステリンを，末たナメクジ，マイマイのステリ ンからエルゴステリンの融点と近いステリンを得た。

Boer はタマキビ Littorina littorea からクロマトグラ フィーで融点 $137.5^{\circ} \mathrm{C} の$ prewinkle provitamin Dを 得たが，Kind らはこの貝のステリン主成分がクリオナ ステリンであり, prewinkle provitamin D の性状が合 成された 7-デヒドロクリオナステリンの性状と一致す るところから同一物と推測した。乙かし貝類の $4^{5,7}$ ーステ リンは 2 種類以上含まれることが多いから, 純粋得離 してその構造を検討する必要があると考光られる。Boer はムラサキイガイからプロビタミンDを得，さらに van der Vliet अムラサキイガイのステリン混合物（プロビ タミン D 6.5\% 含有）を紫外線照射してビタミン D 混 合物を得，これをオゾン分解してホルムアルデヒド，イ ソ吉草酸特よびメチルイソプロピルアセトアルデヒド を得て，ムラサキイガイの $\Delta^{5,7}$ ーステリンとは $\Delta^{5,7,22}$-コ レスタトリエノール，エルゴステリン，7-デヒドロコレ ステリン招よびプロビタミン $\mathrm{D}_{x}$ が含まれるとした。松 本，外山ら ${ }^{49}$ はシジミからコルビステリンを得たが，と の粗製物とついての動物試験で白ネズミそ対しては抗ク 儿病作用はあるが，若鵎化対しては生理作用が微弱なこ とから $\mathrm{C}_{28}$-ステリンであろうとされた ${ }^{50)}$ 。のコルビス テリンはさらと松本, 田村ら ${ }^{51), 21) b}$ 亿よて精製され, 精製物は性状が 7-デヒドロスチグマステリンのそれに 一致し，オゾン分解で $l$-イソプロピルアセトアルデヒ ドを与觉るととがわかつた。

Petering, Waddel はイガイそ似た Modiolus demissusから融点 $127^{\circ} \mathrm{C}$ の抗クル病作用の步るステリンを得 た。このるの招よび誘導体の性状は 7-デヒドロコレス テリンのそれると似ているが，二量体江和いて異なり， また誘導体のケン化当量からこのステリンは $\mathrm{C}_{29}$ である としている。田中, 外山ら ${ }^{521}$ 快ツシロガイのステリン が比輘的低融点であることを見いだし，これる精製して 融点 $119^{\circ} \mathrm{C} の \Delta^{5,7}$ ーステリンを得た。そしてその赤外部䀦 收スペクトルの吸収極大から $4^{5,7,22,25}$-コレスタテトラ エノールとしているが，ビニリデン結合の吸収極大が弱 すぎるようである。一般に貝類のステリン中には $4^{5,7}$ ステリン含有率が高く，多いものは 50\% 飞及ぶ。

\section{植 物 界}

顕花植物のステリンで現在までそ構造の明らかにされ たものは、いずれも $\mathrm{C}_{28}$ または $\mathrm{C}_{29}$ で， $\mathrm{C}_{24}$ 亿a配置ま たはb配置のメチル基やエチル基が結合している。そし
て，しぶしば配糖体となつて存在している (phytosterolins)。

シトステリンは植物と最も広く含まれるステリンで, その発見は古く 1891 年沈かのぼるが，原料汇よつ て, また研究者によつて得られるシトステリンの性状 は異なつていた。Anderson らはコメヌカ, トウモロコ シ，コムギ肧䓔（はいが）などからシトステリンを得 て, 組織的飞何十回子分別結晶を行いジヒドロー $\beta$-シト ステリン, $\gamma$-シトステリン, $\beta$-シトステリン招よび $\alpha$ シトステリンの分離に成功して, シトステリンなるもの

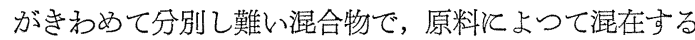
ステリンの種類招よび量が異なつていることを示した。 またステリン以外飞る高級アルコール，炭化水素，トリ テルペンなぞが混入する招それる岕ると考光られる。こ の $\alpha$-シトステリンはさらに $\alpha_{1}$-シトステリン， $\alpha_{2}$-シト ステリン， $\alpha_{3}$-シトステリンと分別された。いずれる構 造が不明でめるが， $\alpha_{2}$-シトステリンは $\mathrm{C}_{30}$ とされてい る。その旋光度の関係からトリテルペンではないかと思 われる。ßーシトステリンは綿実やトール油なぞの主ス テリンで，これから比較的純粋得やすいが，乞れです な特他のステリンを含えでいる。このステリンはスチグ マステリンの部分還元で純粋儿得られる。このこと特よ びジヒドロー $\beta$-シトステリンがスチグマスタノールに一 致することから構造が明らか、された。な特とのステリ ンは植物以外飞も貝，イソギンチャク，オキノテズルモ ズルに含なれることが外山ら ${ }^{31}$ とって見いだされた。 またこのステリンは高等動物の体内ではコプロシトスタ ノールになることが Rosenheim ら ${ }^{53}$ とよつて示され ている。ケーシトステリンは大豆油の主ステリンである が，コムギ肧芽油，ライムギ肧芽油なぞとる含まれてお り，少量は種々の植物炕広く存在するらしい。このステ リンの構造は酸化汇よて左旋性の側鎖分解物が得られ ところから $\beta$-シトステリンの C-24 エピマーとされた が，この酸化分解物の他の生成物が $\beta$-シトステリンの それと一致しないので， $\beta$-シトステリンの $\mathrm{C}_{24}$ 以外飞る さら他の炭素原子の異性配置が荐党られた。乙かしこ れとついて Bergmann は前記動物から得られるクリオ ナステリンと同一であるとした。両者の性状には多少の 差異があり，純度の検討る必要であるう。

大豆油のステリンは主成分が $r$-シトステリンである が，その他 $25 \%$ 内外がスチグマステリンである。この

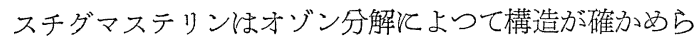
れ，主として四臭化物として分別されて物り，重要な小 ルモン製造原料である。このステリンは淡水藻 ${ }^{54}$ 亿も含 まれまを動物含まれるかどうかということがしばし

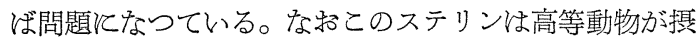
取しても変化を受けないで排せつされる゙5)。

スピナステリンはホーレン草から最初得られ，ムラ 
サキウマゴヤシとも含まれているが，混合物であること

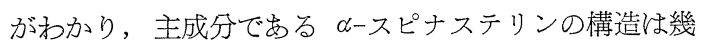
多の研究で明らかねされた。側鎖はオゾン分解でスチグ マステリンのそれ西致する。核の不飽和はいろいろ問 題になつたが，結局 Barton亿よつて旋光性から $\Delta^{7}$ とさ れ，さらに Fieser そよつて7-デヒドロスチグマステリ ンの部分還元によつて $\Delta^{7,22}$ 結合と確認された。 $\Delta^{7}$ 結合の 白金触媒一䣷酸溶媒，またはパラジウム触媒飞よる $\Delta^{8(14)}$ 結合への異性化の性質も長らく不明であつた。このステ リンはナンバンカラスウリ根 ${ }^{55)}$, 茶葉 ${ }^{56)}$, ホウセン花種 子 $^{56)}$, さら飞動物界でヒトデ22) (ヒトデステリン) に含 まれるとこが明らか机なつた。

ホーレン草葉やムラサキウマゴヤシ葉拉よび種子には

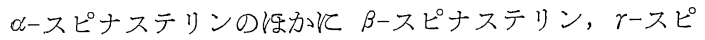
ナステリン， $\delta$ ースピナステリン ${ }^{57}$ が含まれ，いずれも異 性化觉伴なう条件で部分還元して $\Delta^{8(14)}$ ースチグマステノ 一ルを与光るところから $\Delta^{7}$-ステリンで，側鎖には $\Delta^{22}$ 以外の不飽和結合があるとされているが，その後の研究 はあとをたつている。

十字科のナタネからブラシカステリンが Windaus ら によつて得られたが，これは還元によつてエルゴスタノ ールと一致する。また Fernholz はカンペステリンを見 いだしたが，酸化生成物が左旋性 5,6-ジメチルヘプタ

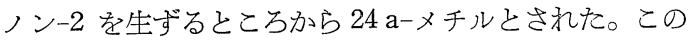
ステリンは大豆油，コムギ胚芽油飞も含まれる。

な特影花植物にはこれらのステリンの注か、 $\mathrm{C}_{30}$ のス テリンも報告されている。ヌカ油から得られるオリザノ 一ル ${ }^{58}$ はシクロアルテノールあるいは同族体のフェルラ 酸エステル ${ }^{59)}$ で，ナタネ油なぞ飞も存在し60)，ぬたシク ロアルテノールはオリステリンやコムギ泼芽油から得ら れたトリチステリン廌致すると考光られる。

隠花植物のステリンは菌類について良く研究されてい る。酵母のステリンの主成分はエルゴステリンであり， ブドウ糖やその他の炭水化物から生成される。これらの なか、注 $2 \%$ から含まれるので, 工業的ともプロビタミ ンDの製造が行われている。エルゴステリンは菌類以外 飞地衣類に存在するが, さらに緑藻にも含季れる。また 試料が発䤃して粗ステリン中に二次的と含李れる場合る ある。正油の油中 ${ }^{61)}$ のまた虫㷶中のエルゴステリン ${ }^{622}$ はこのようなるのである。

菌類にはエルゴステリンのほか、アスコステリン，フ エコステリン，アナステリン，ヒポステリンなぞ，また 斎藤 ${ }^{63)}$ 亿よるファンジステリン $\left(\Delta^{6,8,22}\right)$ が知られてい

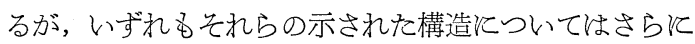
確認が必要であると考克られる。また 5-ジヒドロエル ゴステリン，22-ジヒドロエルゴステリン，千モステリ ンが存在するが，前二者はエルゴステリンの部分還元に よつて構造も明らかでめる。チモステリンは植物界とめ

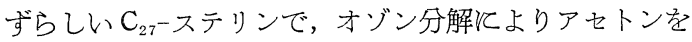
与光，部分還元で $\Delta^{8}$-コレステノールを与光る。 $\Delta^{8}$ 結合 性白金触媒一酶酸溶媒で $\Delta^{8(14)}$ 飞異性化され，さら飞塩 化水素で $1^{14}$ 亿異性化されてはじめて還元される。また これらのステリンのほか汇近年 14-デヒドロエルゴステ リン特よび 24-デヒドロエルゴステリンが発見された。 前者は Barton らが青カビから得たもので, 核に共役卜 リエン $\left(\lambda_{\max } 319 \mathrm{~m} \mu\right)$ をるつ特殊構造のるのである。後 者はBreivik らによつて酵母からのエルゴステリンの再 結晶母液飞認められたもので, 核捛よび側鎖に 2 組の共 役ジエン結合 $\left(\lambda_{\max } 230 \mathrm{~m} \mu, 281.5 \mathrm{~m} \mu\right)$ をるつている。 両者とる天然ステリンでは不飽和度が最高 $\left(F_{4}\right)$ であ る。

\section{表-2}

\begin{tabular}{|c|c|c|c|c|}
\hline & & 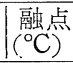 & {$[\alpha]_{\mathrm{D}}$} & 存 \\
\hline ラノステリン & $\Delta^{8,24}$ & 141 & $+58^{\circ}$ & $\begin{array}{l}\text { 羊毛脂, 酵母, } \\
\text { バター }\end{array}$ \\
\hline ラノステノール & $\Delta^{8}$ & 144 & $+61^{\circ}$ & 羊毛脂 \\
\hline アグノステリン & $\Delta^{7,9(11), 24}$ & 165 & $+77^{\circ}$ & " \\
\hline $\begin{array}{l}\text { ジヒドロアグノステ } \\
\text { リン }\end{array}$ & $\Delta^{7,9(11)}$ & 158 & $+68^{\circ}$ & $\begin{array}{c}\text { " } \\
\text { ナガミパンの木 }\end{array}$ \\
\hline シクロアルテノール & $\Delta^{24}$ & 115 & $+54^{\circ}$ & 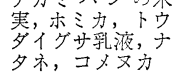 \\
\hline シクロラウデノール & $\Delta^{25} \mathrm{C}_{31}$ & 125 & $+46^{\circ}$ & アヘン \\
\hline シクロユーカレノー & $J^{24(28)} \mathrm{C}_{31}$ & 140 & $+46^{\circ}$ & ユーカリ \\
\hline ユーホール & $\Delta^{8,24}$ & 116 & $+32^{\circ}$ & $\begin{array}{l}\text { トウダイグサ } \\
\text { 烰液 }\end{array}$ \\
\hline ブチロスパーモール & $\Delta^{7,24}$ & 113 & $-12^{\circ}$ & シアー脂 \\
\hline チルカロール & $J^{8,24}$ & 135 & $+5^{\circ}$ & $\begin{array}{l}\text { 卜ウダイグサ } \\
\text { 乳液 }\end{array}$ \\
\hline $\alpha$ ユーホルボール & $\begin{array}{r}V^{8,24(28)} \\
\mathrm{C}^{2}\end{array}$ & 127 & $+0^{\circ}$ & ज仵 \\
\hline ダマラジエノール & $\Delta^{20,24}$ & 138 & $+47^{\circ}$ & ダマー樹脂 \\
\hline
\end{tabular}
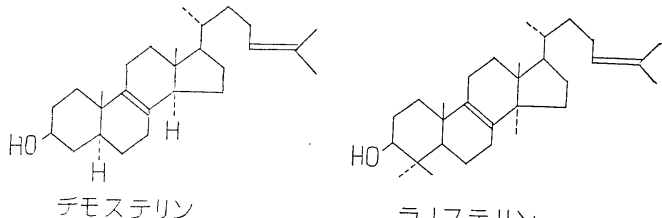

テモステリン

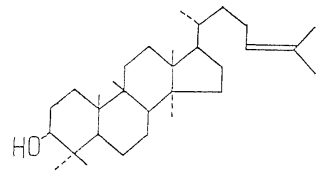

シフロアルテノール

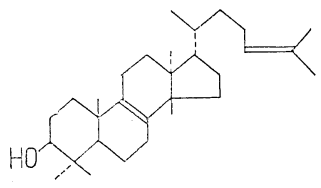

テルカロール

$$
\text { ラノステリン }
$$
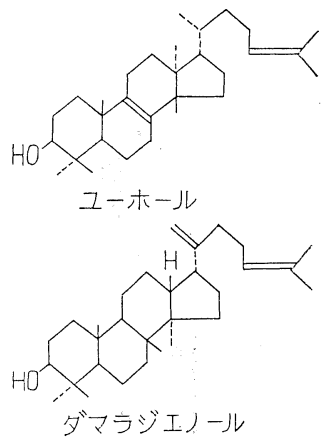
澡類のステリンとしてはフコステリンが良く知られて いる。このステリンが褐藻から発見されたころ, 本邦で る白浜 ${ }^{641}$ は同一のステリンを得てペルベステリンと命名 している。 オゾン分解でアセトアルデヒド，24-ケトコ レステリンを与光，還元ではスチグマスタノールを与光 る。さきの 24-メチレンコレステリン (やほり $\Delta^{24(28)}$ 結 合をもつ) では $24 \mathrm{a}$ 配置の還元生成物となるが，フコ ステリンの場合は $24 \mathrm{~b}$ 配置の生成物ということそなる。 その他緑藻からコンドリラステリンが分離されている。 また津田, 赤木らは褐藻才オバモクにフコステリンと性 状を異にする20a のサーガステリンを報告している ${ }^{65)}$ 。

最近津田, 赤木らはアカバギンナン草なぞ数種のテン グサ目の紅藻からコレステリンを分離したと報告してい る66。植物界とコレステリンの存在は知られていないの でこの報告はステリンの分布上はなはだ興味あるととで ある。な物紅藻からはチャリナステリン(24-メチレンコ レステリン) の存在が伊藤, 松本ら ${ }^{67}$ 《よつて報告され ている。

\section{VI. トリメチルステロイド・アルコール}

羊毛脂からイソコレステリンが得られ(1872)，これが ラノステリンとアグノステリンなどの混合物であること が明らか、され，また䤉母からのクリプトステリンがラ ノステリンと同一物であるととがわからたが，これらの 構造が判明したのは近年のととでラノステリンはコレス テリン核を基本とすれば 4, 4'-ジメチル-14-メチルーチ モステリンであることが確認された。このようなコレス テリン骨核にさらにメチル基 3 個置換した構造のトリメ チルステロイドが数種明らかマされている。これらを一 価アルコールのみと限定して示せば 衰-2 のと和りであ る（骨核の炭素の番号順位をトリテルペンと同様の順位 で表わす方法もある ${ }^{6)}$ 。

ラノステリンは羊毛脂のイソコレステリンの主成分を なして招り，ジギトニンとよつてアルコール難溶性の付 加物を作るが，その水素添加物ラノステノールは㴽とえ ぞ沈殿しない。Liebermann-Burchard 反応では緑色螢 光をるつた褐色呈し，先の吸收極大法 $550 \mathrm{~m} \mu$ を示 す。また Salkowski 反応では黄色から褐赤色飞变る呈 色をする。アグノステリンはラノステリン飞付随して羊 毛脂存在するが，核に共役二重結合をもつので 240 $245 \mathrm{~m} \mu$ 飞吸収極大を紫外部吸収スペクトルで示す。う

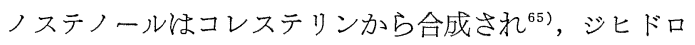
アグノステリンとリチウムを作用しても得られる。ジヒ ドロアグノステリンはラノステノールを酸化セレン, 過 安息香酸，コハク酸イミドブロミドなぞとよつて脱水素 異性化して得られる ${ }^{69)}$ 。

シクロアルテノールはナガミパンノ木の実の成分飞命 名 ${ }^{70)}$ されたが，トウダイグサのラテックスやホミカ実に
も含まれ，さら飞太田，清水 ${ }^{59}$ そよつてオリザノールの アルコール成分の一つとしす, また田村, 松本 ${ }^{60}$ 亿よつて

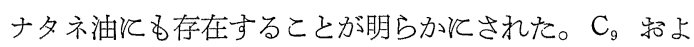
び $\mathrm{C}_{19}$ で環化してシクロプロパン構造をなして招り，赤 外部吸収スペクトルで $3040 \mathrm{~cm}^{-1}$ 付近和よび $1000 \mathrm{~cm}^{-1}$ 飞吸收極大を示す。このシクロプロパン環は塩化水素に よつて開環され, シクロアルテノールは $4^{9(11), 24}$ アルタ ジエノ一ル和よびラノステリン ${ }^{60}$ を与学る。チモステリ ンの $\Delta^{8}$ 一結合は酶酸溶㷊での遷元によつて $\Delta^{(14)}$ そ移る が，ラノステリンでは $\mathrm{C}_{14}$ 亿置換基がめるので二重結合 は $\Delta^{8(14)}$ V移らない。

このようなシクロプロパン環をるつトリメチルステロ イドは,上記の法か、アアンかからクロラウデノール ユーカリ樹からシクロユーカレノール年な゙゙が知られて いる。両者とる $\mathrm{C}_{31}$ であるが，還元生成物の性状はあま り一致していない。前者は24b-メチルの配置とされ, 後者は $\mathrm{C}_{17}$ あるいはさらと $\mathrm{C}_{20}$ の置換基がラノステリン 系とは異なるとされている。またオリザノ一ルのアルコ 一ル成分として吉田ら ${ }^{72}$ は $\left(\mathrm{C}_{31}, 4^{25}\right)$ を発表しているが，乙れの還元生成物の性状 も上記二者の $\mathrm{C}_{31}$ の性状とは異なつている。

付記 最近フジッボから 24-デヒドロコレステリン (融点 $118^{\circ} \mathrm{C},[\alpha]_{\mathrm{D}}-38^{\circ}$ ) が分離された

\section{文献}

1) W. Bergmann, "Sterols" Progress in the Chemistry of Fats and other Lipids, Vol. 1 Pergamon (1952)

2) 毛利, “天然ステロイドの完全合成まで”化学の 領域 6, 20,92,178, 294, 351, 474,602,677, 751 (1952).

3）松本, “ステリン”脂質化学, 共立出版 (1958)

4) A. Georg, "Steroids" Elsevier's Encyclopedia of Organic Chemistry, Vol 14 (1940) \& Supplement (1954).

5) L.F. Fieser, M. Fieser, "Natural Produccts Related to Phenanthrene", 3 rd. Ed. Reinhold (1949)

6) C. W. Shopee, E. Shopee, "Steroids" Chemistry of Carbon Compounds (E.H. Rodd), Vol. II, Elsevier (1953)

7) J.W. Cornforth, R. Robinson, J. Chem. Soc. 1949, 1855; 1953, 361

8) R.B. Woodward, F. Soundheimer, D. Taub, K. Heusler, W.M. MacLamore, J. Am. Chem. Soc., 74, 4223 (1952)

9) H. Reich, A. Lardon, Helv. Chim. Acta, 29, 671 (1946); W. Dauben, J.E. Eastham, J. Am. Chem. Soc., 72, 2305 (1950); A.J. Birch, J. Chem. Soc., 1950, 2325; B. Bellean, T.F. Gallagher, J. Am. Chem. Soc., 73, 4458 (1951)

10) H.N. Little, K. Bloch, J. Biol. Chem., 183, 33 (1950)

11) D.R. Idler, C.A. Baumann, J. Biol. Chem., 203, 389 (1953)

12) 中西, B.K. Bhattacharyya, L.F. Fieser, J. Am. Chem. Soc., 75, 4415 (1953) 
13) R. Shoenheimer, Z. Physiol Chem., 192, 77 (1930)

14) 桑田, “ステロイドと旋光性" 化学の領域, 臨時 增刊 2, 13 (1949)

15) S. Bernstein, E.J. Wilson, E.S. Wallis, $J$. Org. Chem., 7, 103 (1942)

16) D.H.R. Barton, J. Chem. Soc., 1945, 813; 1946, 512

17) D.H.R. Barton, T. Brunn, J. Chem. Soc., 1951 , 2728

18) L. Dorfman, "Ultraviolet Absorption of Steroids" Chem. Rev., 53, 47 (1953)

19) K. Dobriner, E.R. Katzenellenbogen, R.N, Jones, "Infrared Absorption Spectra of Steroids, an Atlas" Interscience (1953)

20) R.B. Woodward, J. Am. Chem. Soc., 64, 72 (1942)

21） a) 松本, 田村, 伊藤，日化，76，953 (1955) b) 田村，国馬，松本，日化，77，987 (1956)

22) O.N. Breivik, J.L. Owades, R.F. Light, $J$. Org. Chem., 19, 1734 (1954)

23）伊藤, 田村, 松本, 日大工研棵報 13, 1 (1956)

24) D.R.Idler, U.H.M. Fagerlund, J. Am. Chem. Soc., 77, 4142(1955); U.H.M. Fagerlund, D.R. Idler, J. Org. Chem., 21, 372 (1956)

25) W. Bergmann, "The Plant Sterols", Ann. Rev. Plant Physiology, 4, 383 (1953)

26) W. Lange, J. Am. Oil Chemists' Soc., 27, 414 (1950)

27) 石黒, 渡辺, 薬学, 58, 970 (1938)

28) 大滰, 薬学, 71, 742,744,751 (1951)

29) 桑田, 矢後, 薬学, 57, 963 (1937)

30) W. Bergmann, J.P. Dusza, Ann., 603, 36 (1957)

31）外山, 高木, 日化, 75, 1238 (1954)； 76, 237 (1955)； 77, 105 (1956)

32) 松本, 外山, 日化, 64, 1069, 1203 (1943); 松本, 和井内, 日化, 75，1147 (1954); Bull. Chem. Soc. Japan, 28, 448 (1955); 外山, 高木, Bull. Chem. Soc. Japan, 28, 469 (1955)

33) 松本, 和井内, 日化, 75, 756 (1954); 外山, 高 木, Bull. Chem. Soc. Japan, 27, 421 (1954); 松本, 和井内, 平井, 日化, 77, 531 (1956) 外山, 高木, Bull. Chem. Soc. Japan, 29, 317 (1956)

34）高木, 外山, 日化, 78, 93 (1957)

35) 松本, 田村, 日化, 77, 376 (1956)

36) 桑田, 伴, 薬学, 69, 212 (1949)

37 ) 東，水産試験場報告，第 7 号 (1936)

38）辻本，小柳，工化，37，175, 181,998 (1934)

39) 辻本, 小柳, 工化, 38, 270 (1935)

40) 松本, 外山, 日化, 65, 258, 310 (1944)

41) W. Bergmann, R.C. Ottke, J. Org. Chem., 14, 1085 (1949); J. van der Vliet, Rec. trav. chim., 66, 83 (1947)

42) 桑田, 吉城, 薬学, 61, 407 (1941)
43）足利, 農化, 31, 115 (1957)

44) D.R. Idler, U.H.M. Fagerlund, J. Am. Chem. Soc., 79, 1988 (1957)

45）外山, 高木, Bull. Chem. Soc. Japan, 27, 421 (1954)

46) C.A. Kind, R.A. Meigs, J. Org. Chem., 20, 1116 (1955)

47) 松本, 田村，日化，76，951 (1955)

48）田中, 外山, 日化, 70, 1101 (1957)

49) 松本, 外山, 日化, 64, 326 (1943); 外山, 喜多, 田中, Bull. Chem. Soc. Japan, 25, 355 (1952)

50) H.R. Rosenberg, Arch. Biochem. \& Biophys. 58, 256 (1955)

51）松本, 田村, 日化, 76, 1413 (1955)； 77, 1596 (1956)

52) 田中, 外山, 日化, 78, 665 (1957)

53) O. Rosenheim, T.A.Webster, Biochem. J. 35, 928 (1941)

54) 松本, 平井, 日化, 76, 830 (1955)

55) 桑田, 吉城, 薬学, 57, 695 (1937)

56) 松本, 植山, 平井, 日化, 75, 346 (1954) 松本，和井内，三宅，日化，76，1057 (1955)

57) 平井, 長縄, 松本, 日化，77，1247 (1956)

58）金子，土屋，工化，57，526 (1954)

59) 太田, 清水, Pharm. Bull., 5, 40 (1957)

60) 田村, 松本, 昭和 32 年 10 月油脂討論会講演物 よび未発表

61) 井爪, 吉丸, 日高, 農化, 9, 1 (1933)

62) 田村, 新谷, 松本, 日化, 77, 1424 (1956) 扮上 び未発表

63) 斎藤, Memoirs Osaka Univ. of Liberal Arts and Education, B. No.2 (1953); 醊酵工学 29, 457 (1951); 31, 140, 141, 328 (1953)

64) 白浜, 農化, 11, 980 (1935)；12, 521 (1936)

65）津田, 赤木, 岸田, 早津, Pharm. Bull., 5, 85 (1957); 早津, Pharm. Bull. 5, 452 (1957)

66) 津田, 赤木, 岸田, Science, 126, 927 (1957)

67) 伊藤, 長島, 松本, 日化 77, 1119 (1956)

68) R.B. Woodward, A.A. Patchett, D.H.R. Barton, D.A. Ives, R.B. Kelly, J. Am. Chem. Soc., 76, 2852 (1954)

69) L.J. Bellamy, C. Doree, J. Chem. Soc., 1941, 172, 176; M.J. Birchennough, J.F. McGhie, J. Chem. Soc., 1949, 2038; C. Doree, J.F. McGhie, F. Kurzer, J. Chem. Soc, 1949, 570, S 167

70) D.H.R. Barton, J. Chem. Soc., 1951, 1444

71) H.R. Bentley, J.A. Henry, D.S. Irvine, D. Mukerji, F.S. Spring, J. Chem. Soc., 1955, 596 ; J.A. Henry, D.S. Irvine, F.S. Spring, $J$. Chem. Soc., 1955, 1607

72) J.S. Cox, F.E. King, T.J. King, J. Chem. Soc., 1956, 1384

73) 吉田, 高崎, 末吉, 薬学 76, 1335 (1956)

74) U.H.M. Fagerlund, D.R. Idler, J.Am. Chem. Soc., 79, 6473 (1957) 